which are applicable to the subject have been kept well in view. And from our standpoint this must be the test of the efficiency of any scheme for the disposal of sewage. We fear that hitherto those with whom the decision rests as to what scheme shall be adopted for the disposal of the sewage of London have looked upon the question too much as one between rival "schemes," and considered far too much the supposed interests of rival "bodies," and too little the clear teachings of science and the welfare of the public. It is evident that for London, at least, the whole subject of the disposal of sewage will have very soon to be reconsidered, and we trust that the authorities concerned will take into their council reputable chemists and physicists, who we are sure, can have no interests more at heart than to see the unmistakeable teachings of science practically applied to the salvation of society.

\section{THE NEW WEALDEN DINOSAUR}

$\Delta \mathrm{T}$ the last meeting of the Geological Society, Mr. A J. Whitaker Hulke, F.R.S., brought forward some new facts concerning the remarkable Dinosaur Ornithopsis, which cannot fail to interest both geologists and naturalists.

In the original collection of Wealden fossils made by Dr. Mantell, and acquired for the British Museum, were two fragmentary bones, the nature of which was somewhat doubtful. Dr. Mantell regarded and figured one of these as a tympanic bone of Iguanodon, at the same time pointing out that it presented some resemblance to a vertebra. Prof. $R$. Owen adopted Mantell's views, and figured it as the tympanic bone of Iguanodon, or, perhaps, of Cetiosaurus or Streptospondylus.

In I869 Prof. H. G. Seeley pointed out that the fossil in question was undoubtedly a portion of a vertebra, and one of a new and very remarkable type. It exhibited points of comparison with the vertebræ of birds, in the lightness of its construction, and in the existence of great cavities penetrating into the centrum. Hence Prof. Seeley suggested for it the generic name of Ornithopsis.

In $1870 \mathrm{Mr}$. Hulke, who was at that time unaware of Prof. Seeley's determination of the vertebral character of the British Museum specimens, gave a description of the neural arch of a vertebra which he had discovered in the Wealden of the Isle of Wight. From the beautiful character of the groined entrance to the neural canal, Mr. Hulke was led to suggest the name of Eucamerotus as a provisional one for the new Dinosaurian genus which the specimen evidently represents.

He especially pointed out as of great interest the enormous size of these vertebræ, and the fact that they are built up of thin plates of very compact osseous tissue, with immense spaces of cancellous tissue between them. At a later date Mr. Hulke recognised the identity of his Eucamerotus with the Ornithopsis of Prof. Seeley.

In 1876 Prof. Owen again took up the study of the forms in the British Museum. He adopted Prof. Seeley's and Mr. Hulke's views as to the vertebral character of the fossils-but he rejected Prof. Seeley's generic narne on the ground that the resemblance between these vertebræ and those of birds is merely superficial, and that the name of Ornithopsis is therefore misleading. Prof. Owen described two new forms presenting this peculiar structure in the vertebral column, and to these he gave the names of Bothriospondylus and Chondrostosatmis; he insisted that the large cavities seen in the fossil vertebræ were probably originally filled with cartilaginous substance, as is the case in the sharks and rays, and argued, therefore, that any comparison with the vertebræ of birds was a misleading one. $\mathrm{Mr}$. Hulke and Prof. Seeley, however, while admitting that the structure does not necessarily imply the powers of flight in the forms possessing it, yet insist that in all probability the cavities in the vertebra were true air-cells, and therefore that the structure is "bird-like;" on these grounds they maintain that the name of Ornithopsis ought not to be superseded.

In I877 Prof. Marsh recognised among the numerous Dinosaurian remains obtained from Colorado a number of gigantic forms with vertebræ presenting the same peculiarities as are found in Ornithopsis; to these forms he gave the names Atlantosaurus, Morosaurus, Apatosaurus, Allosaurus, and Diplocus. Prof. Cope had simultaneously described three other forms-Camarasaurus, Amphicalias, and Epanterias, all presenting the same peculiarities as are found in the English form Ormithopsis. One of the American forms, Atlantosaurus had a femur seven feet in length. When the two distinguished American palæontologists visited this country in 1878 , they both recognised the specimens of Ornithopsis in Mr. Hulke's collection as presenting numerous points of resemblance with the new forms which they had described.

Now in the communication which he has recently made to the Geological Society, Mr. Hulke has described vertebræ from several parts of the spine of Ornithopsis. This he is enabled to do by the courtesy of the Rev. W. Fox, of Brixton in the Isle of Wight, who has long been such an indefatigable collector of the vertebrate fossils of the Wealden, and has permitted Mr. Hulke to make use of his materials. Mr. Hulke shows that while the dorsal vertebræ were closely bound together by processes, so that this part of the spine must have possessed great rigidity, as is the case with birds, the cervical vertebræ indicate the existence of the greatest mobility. But the point on which Mr. Hulke principally insists, from its bearing on the discussion whith has taken place between himself and Prof. Seeley, on the one hand, and Prof. Owen on the other, is that the cavities and cancellous tissue are confined to the dorsal vertebræ, and do not occur in the other portions of the spinal column; this he insists is inexplicable, if, as Prof. Owen insists, the cavities in question had no functional character, but were filled up with cartilaginous tissue, while it finds a ready explanation in the supposition of Prof. Seeley and himself that they are truly pneumatic cavities. Mr. Hulke also points out that there are reasons for believing that some at least of the vertebræ referred to the genus Cetiosaurus belong to the new group of forms to which so much attention has been directed during the last few years.

There can be no doubt that there existed during mesozoic times, both in this country and on the American continent, a group of reptiles of gigantic dimensions, which presented such peculiarities of structure, especially in their vertebral column, that they must be placed in a distant sub-order of the Dinosauria. For this, perhaps the name of Sauropoda, suggested by Prof. Marsh, may be adopted.

The existence of this bird-like character of pneumatic bones in reptiles of such gigantic dimensions as these peculiar Dinosaurs undoubtedly were is certainly very startling and unexpected. At the same time we believe that neither Prof. Seeley nor Mr. Hulke favours the idea that the forms in question were capable of flight. $\mathrm{Mr}$. Hulke promises shortly to add another to his valuable contributions to our knowledge of these forms by describing the limb-bones of Ornithopsis and its allies, and discussing the habits which a study of their structure seems to indicate. All geologists and naturalists will look forward eagerly for the promised memoir.

\section{CASSELL'S NATURAL HISTORY'}

THE third volume of this well-illustrated and popular account of the animal kingdom contains descriptions of the Ruminantia by the late lamented A. H. Garrod,

× Edited by P. Martin Duncan, M.B. (Lond.), F.R.S., F.G.S. Vol. iii. London: Cassell, Petter, and Galpin, 1879 .) 